\title{
КОНЦЕПТУАЛЬНА ФУНКЦІОНАЛЬНО-ОРГАНІЗАЦІЙНА МОДЕЛЬ РЕГІОНАЛЬНОГО ЦЕНТРУ КАРДІОЛОГІЇ НА ПРИНЦИПАХ ДЕРЖАВНО-ПРИВАТНОГО ПАРТНЕРСТВА
}

\author{
Київська обласна клінічна лікарня, м. Київ, Україна
}

\begin{abstract}
Мета: обґрунтувати концептуальну функціонально-організаційну модель регіонального центру кардіології (РЦК) на принципах державно-приватного партнерства (ДПП).

Матеріали і методи. У дослідженні використовували загальнонаукові методи аналізу, синтезу, узагальнення, моделювання, інтерпретації наукових даних, а також системний і структурно-срункціональний підходи.

Результати. Для вирішення проблеми фрінансування та розвитку найбільш витратної третинної високоспеціалізованої кардіологічної допомоги населенню регіону був реалізований проект обґрунтування концептуальної фрункціонально-організаційної моделі РЦК на принципах ДПП, тобто об'єднання сил і засобів держави і бізнесу.

Модель РЦК розроблена як самоврядний, господарсько і юридично самостійний суб'єкт медичної діяльності, що забезпечує оптимальне поєднання державного регулювання і ринкового саморегулювання. Економічна ефективність розробленої моделі РЦК забезпечується за рахунок юридичної та господарської самостійності моделі, багатоканального фрінансування та прибутковості комерційної діяльності.

Медична допомога у моделі РЦК представлена двома напрямками - медико-соціальним (безоплатним) та економічно рентабельним (платним), кожний з яких орієнтований на свого споживача послуг і в цілому забезпечує підтримку кардіологічного здоров'я усіх верств населення регіону.

Організаційна структура моделі РЦК на принципах ДПП інтегрує три центри: центр високоспеціалізованої стаціонарної допомоги, центр консультативної амбулаторно-поліклінічної екстреної і планово-консультативної допомоги, центр організаційно методичної, інфрормаційно-аналітичної, інтеграційної та статистичної роботи, а також два блоки - адміністративно-господарський та допоміжних підрозділів.

Пацієнторієнтованість моделі забезпечує доступність високоспеціалізованої медичної допомоги для різних категорій населення.

Висновки. Потенціал моделі РЦК на принципах ДПП орієнтований на бізнес-процеси та інтегрування медичних послуг, забезпечує ії економічну, медичну і соціальну ефективність та оптимальне фрункціонування у ринкових умовах. Реалізація моделі РЦК на практиці дасть змогу виконати її цільову функцію - задовольнити потреби населення регіону в доступних і якісних високотехнологічних кардіологічних послугах.
\end{abstract}

КЛЮЧОВІ СЛОВА: регіональний центр кардіології; державно-приватне партнерство; третинний рівень кардіологічної допомоги; фрінансування медичної допомоги.

На даний час в Україні стає очевидним, що модернізація закладів державного сектору системи охорони здоров'я, їх фрінансування можуть бути ефективними лише при інтеграції інтересів держави, бізнесу і пацієнтів [1-3]. Необхідність організації системи охорони здоров'я на засадах державно-приватного партнерства стала об'єктивною реальністю на сьогодні [4-6]. У розвинутих країнах світу державно-приватне партнерство широко використовують як систему відносин держави і бізнесу, як інструмент національного, міжнародного, регіонального, міського, муніципального економічного і соціального розвитку $[10,11]$.

Мета роботи: обґрунтувати концептуальну фрункціонально-організаційну модель регіонального центру кардіології (РЦК) на принципах державно-приватного партнерства (ДПП).

Матеріали і методи. У дослідженні використовували загальнонаукові методи аналізу, синтезу, узагальнення, моделювання, інтерпретації наукових даних, а також системний і структурнофрункціональний підходи.

(c) А. В. Іванюк, 2021
Результати дослідження та їх обговорення. Інноваційна концептуальна модель РЦК на принципах ДПП розроблялася на основі визначених концептуальних і методичних підходів, вивчення літературних джерел, аналізу результатів проведеного соціологічного дослідження та експертиз. Модель фрормувалася як юридично і господарсько самостійний суб'єкт, який надає медичні послуги в умовах ринкової економіки.

Базовим нормативно-правовим актом, що регулює діяльність моделі РЦК, є Конституція України. Норми і правові положення щодо ДПП в Україні сорормульовані у таких законах:

- Закон України «Про державно-приватне партнерство» від 01.07.2010 р. № 2404-VI [7];

- Закон України «Про внесення змін до деяких законів України щодо усунення регуляторних бар'єрів для розвитку державно-приватного партнерства та стимулювання інвестицій в Україні» від 24.11.2015 р. № 817-VIII [8];

- Закон України «Про внесення змін до деяких законодавчих актів України щодо удосконалення законодавства з питань діяльності закладів охорони здоров'я» від 06.04.2017 р. № 2002-VIII [9]. 
Основною метою діяльності моделі РЦК є:

- забезпечення оптимального державного регулювання і ринкового саморегулювання для формування сприятливого поєднання соціальних і юридичних правил, що утворюють базис-моделі;

- забезпечення доступності високоспеціалізованої медичної допомоги для різних категорій громадян регіону в рамках платних медичних послуг і програм державних гарантій;

- надання медичних послуг, обсяги, види і якість яких відповідають рівню захворюваності та потребам населення регіону.

У реалізації цілей модель РЦК спирається на:

- повне узгодження розподілу можливих ризиків 3 усіма залученими до ДПП сторонами та збільшення показників економічного зростання і розвитку;

- стабільне фрінансування і технічне забезпечення моделі;
- фрактори ефективного управління;

- врахування потреб та побажань населення.

У своїй діяльності модель РЦК керується спеціально розробленим статутом закладу. Керуючі та регулюючі дії у моделі РЦК фріксують в угодах, контрактах, договорах у вигляді зобов'язань, умов і т. д.

Модель РЦК є профрільною клінічною установою $з$ питань кардіології, хірургії серця і магістральних судин, рентгеноендоваскулярної діагностики та лікування, яка орієнтована на підвищення якості найбільш витратної кардіологічної медичної допомоги третинного рівня.

У процесі розробки концептуальної структури моделі РЦК здійснено логічне моделювання трьох фрункціональних центрів, адміністративногосподарського блоку та допоміжних підрозділів (рис. 1).



Puc. 1. Схема структури функціонально-організаційної моделі РцК на принципах державно-приватного партнерства.

Структура фрункціонально-організаційної моделі РЦК, як форма системного підходу до організації медичної допомоги населенню регіону, фрункціонально об'єднала елементи системи маркетингу медичних послуг, що дає змогу виконати цільову фрунццію моделі - задоволення потреб населення регіону у високотехнологічних кардіологічних медичних послугах.
Центр високоспеціалізованої стаціонарної допомоги є базовим стаціонарним підрозділом моделі РЦК, котрий інтегрує у своєму складі відділення кардіохірургії та відділення терапевтичної кардіології.

Діяльність відділення кардіохірургії визначає цілий ряд вузькоспеціалізованих напрямків: хірургія набутих і уроджених вад серця, хірургія 
ішемічної хвороби серця, хірургія порушень ритму серця, хірургія патології аорти, хірургія патології міокарда.

У відділенні терапевтичної кардіології проводять спостереження за пацієнтами 3 гіпертонічною хворобою, ішемічною хворобою серця, гострим інфарктом міокарда, різноманітними видами аритмій, уродженими і набутими вадами серця і т. д.

Предметом діяльності центру консультативної амбулаторно-поліклінічної екстреної і планово-консультативної допомоги є: реалізація комплексу поліклінічної екстреної і плановоконсультативної допомоги населенню регіону, зниження кардіологічної захворюваності, інвалідності, передчасної смертності. Надання консультативної, організаційно-методичної допомоги закладам охорони здоров'я регіону 3 питань кардіології, рентгеноендоваскулярної діагностики та лікування, хірургії серця і магістральних судин, судинної хірургії та трансплантології.

Ключовим принципом функціонування центру високоспеціалізованої стаціонарної допомоги і центру консультативної амбулаторно-поліклінічної екстреної і планово-консультативної допомоги $€$ надання високотехнологічної медичної допомоги висококваліфікованим персоналом на базі інноваційних організаційно-технологічних лікувальних програм із забезпеченням конкурентоспроможності медичних послуг.

Управління лікувально-діагностичним процесом здійснюється за допомогою бізнес-процесів, спрямованих на пацієнторієнтованість і на планування структурної ефективності діяльності моделі РЦК на базі:

- стандартизації медичних послуг;

- визначення нормативів вартості одиниці медичної послуги;

- обліку витрачених коштів на стаціонарні та амбулаторно-поліклінічні види медичних послуг з виділенням зон неефективності використання;

- корекції об'ємних показників медичної допомоги;

- розробки показників ефективності матеріальних, фрінансових і трудових ресурсів та створення механізмів поточного планування і оцінки бізнеспоказників діяльності моделі РЦК, які б дали змогу вже на стадії складання завдань враховувати пріоритети і орієнтири в роботі моделі.

Джерела фрінансування моделі РЦК з механізмами ДПП багатоканальні:

- приватні інвестиції;

- бюджет державного обласного, міського управління;

- платні послуги;

- програми медичного страхування;

- благодійні внески;

- договірні роботи;

- пожертвування організацій, установ і громадян.

В умовах ринку і багатоканального фрінансування діяльності моделі РЦК бізнес-процеси спираються на цінові орієнтири вартості одиниці медичної послуги та покликані:
- забезпечити відшкодування витрат (медикаменти, продукти харчування і т. д.) на надання медичної допомоги;

- забезпечити дохід для утримання медичних установ моделі та персоналу.

Такий підхід $є$ запорукою успіху в наданні високоспеціалізованої медичної допомоги із дотриманням стандартів і 3 використанням новітніх медичних технологій, стаціонарної, лікувально-профрілактичної та реабілітаційної медичної допомоги пацієнтам із серцево-судинними захворюваннями при найбільш ефективному використанні ресурсів - капіталу, матеріалів, праці.

У цілому концептуальна функціонально-організаційна модель РЦК на принципах ДПП несе свій сучасний потенціал, що забезпечує її роботу в ринкових умовах - це:

- державно-приватна фрорма власності, юридична і господарська самостійність;

- механізм державного контролю над діяльністю і збереження закладу у власності держави;

- профресіоналізм і досвід приватного сектору в розвитку управління та господарської діяльності, сучасних фрорм фрінансування;

- багатоканальне фрінансування, прибутковість комерційної діяльності;

- оснащення високотехнологічним медичним обладнанням та висококваліфікованими кадрами;

- перехід від фрілософії споживання до фрілософії заробітку;

- підвищення якості матеріально-технічної бази, ресурсного забезпечення, рівня відбору та підготовки кадрів;

- підвищення економічної стійкості та конкурентоспроможності;

- впровадження автоматизованої інформаційної системи;

- пацієнторієнтованість, спрямованість на забезпечення доступності допомоги для різних категорій населення за рахунок платних послуг та соціальних державних програм;

- механізми економічного стимулювання медичних працівників за якість послуг.

\section{Висновки}

Розроблена концептуальна фуунціональноорганізаційна модель регіонального центру кардіології на принципах ДПП, яка є самоврядним, господарсько і юридично самостійним суб'єктом медичної діяльності, що забезпечує оптимальне поєднання державного регулювання і ринкового саморегулювання. Потенціал моделі орієнтований на бізнес-процеси та інтегрування медичних послуг, забезпечує її економічну, медичну і соціальну ефективність та оптимальне функціонування в ринкових умовах. Реалізація моделі РЦК на практиці дасть змогу виконати її цільову фрункцію - задовольнити потреби населення регіону в доступних і якісних високотехнологічних кардіологічних послугах.

Перспективи подальших досліджень полягають у використанні отриманих результатів для обґрунтування регіональних моделей РЦК на принципах ДПП. 


\section{Список літератури}

1. Аджиенко В. Л. Стратегический анализ института государственно-частного партнерства в сорере здравоохранения / В. Л. Аджиенко, Н. Н. Косинова // Фармация и фрармакология. - 2017. - Т. 5, № 4. - С. 380-400.

2. Борщ В. І. Державно-приватне партнерство як запорука інноваційного розвитку національної галузі охорони здоров'я / В. І. Борщ // Вісник ЖДТУ. - 2019. - № 2 (88). - С. 156-162.

3. Вахитов Р. Н. Механизм государственно-частного партнерства и его роль в развитии региона [Электронный ресурс] / Р. Н. Вахитов. - Режим доступа : http://teoria-practica.ru/rus/files/arhiv_zhurnala/2017/2/economics/vakhitov. pdf (дата обращения 21.07.2020).

4. Вовк С. М. Інституційні десрініції розуміння державно-приватного партнерства в медицині / С. М. Вовк // Держава та регіони. - 2016. - № 3 (55). - С. 23-27. - (Серія «Державне управління»).

5. Вовк С. М. Механізми державного управління системними змінами у сорері охорони здоров'я : дис. ... доктора мед. наук : 25.00.02 / С. М. Вовк. - Маріуполь, 2019. - 440 с.

6. Голованова І. А. Значення приватної медицини в системі охорони здоров'я України / І. А. Голованова, О. І. Краснова // Економіка і право охорони здоров'я. - 2016. - № 1 (3). - С. 22-24.

7. Про внесення змін до деяких законодавчих актів України щодо удосконалення законодавства з питань діяльності закладів охорони здоров'я : Закон України від 06.04.2017 р. № 2002-VIII [Електронний ресурс]. - Режим доступу : https://zakon.rada.gov.ua/laws/show/2002-19\#Text.

8. Про внесення змін до деяких законів України щодо усунення регуляторних бар'єрів для розвитку державноприватного партнерства та стимулювання інвестицій в Україні : Закон України від 24.11.2015 р. № 817-VIII [Електронний ресурс]. - Режим доступу : https://zakon.rada. gov.ua/ laws/show/817-19.\#Text.

9. Про державно-приватне партнерство : Закон України із змінами, внесеними згідно із Законами ВВР від 21.06.2012 p. № 5007-VI (5007-17), від 16.10.2012 р. № 5463-VI [Електронний ресурс] // Відомості Верховної Ради України. - 2010. - № 40. - Ст. 524. - Режим доступу : https://zakon.rada.gov.ua/laws/show/2404-17\#Text.

10. Кредисов А. И. Государственно-частное партнерство: мировой опыт и его использование в Украине / А. И. Кредисов, А. А. Билоус // Економіка України. - 2016. - № 2 (643). - С. 5-15.

11. Крутій О. М. Основи партнерської взаємодії держави і приватного сектора / О. М. Крутій, О. В. Радченко // Теорія та практика державного управління : зб. наук. пр. - Львів : Вид-во ЛРІ НАДУ, 2018. - Вип. 3 (50). - С. $73-83$.

\section{References}

1. Adzhienko, V.L. \& Kosinova, M.M. (2017). Stratehichnyy analiz instytutu derzhavno-pryvatnoho partnerstva $v$ sferi okhorony zdorovya [Strategic analysis of the institute of public-private partnership in the field of health care]. Farmatsiya $i$ farmakolohiya - Pharmacy and Pharmacology, 5(4), 380-400 [in Russian].

2. Borshch, V.I. (2019). Derzhavno-pryvatne partnerstvo yak zaporuka innovatsiynoho rozvytku natsyonalnoi haluzi okhorony zdorovya [Public-private partnership as a guarantee of innovative development of the national health care sector]. Visnyk ZhDTU - Bulletin of ZhSTU, 2 (88), 156-162 [in Ukrainian].

3. Vakhitov, R.N. (2017). Mekhanizm derzhavno-pryvatnoho partnerstva ta yoho rol u rozvytku rehionu [The mechanism of public-private partnership and its role in the development of the region]. Retrieved from: http://teoria-practica.ru/rus/files/ arhiv_zhurnala/2017/2/economics/vakhitov.pdf [in Russian].

4. Vovk, S.M. (2016). Institutsiyni definitsiyi rozuminnya derzhavno-pryvatnoho partnerstva $\vee$ medytsyni [Institutional definitions of understanding public-private partnership in medicine]. Derzhava ta rehiony. Seriya: Derzhavne upravlinnya State and regions. Series: Public Administration, 3 (55), 23-27 [in Ukrainian].

5. Vovk, S.M. (2019). Mekhanizmy derzhavnoho upravlinnya systemnymy zminami u sferi okhorony zdorov'ya [Mechanisms for public management of systemic changes in health care]. Doctor's thesis. Mariupol [in Ukrainian].

6. Holovanova, I.A. \& Krasnova, O.I. (2016). Znachennya privatnoyi medytsyny v systeme okhorony zdorovya Ukrayiny [The value of private medicine in the health care system of Ukraine]. Ekonomika i pravo okhorony zdorovya - Economics and Law of Health Care, 1 (3), 22-24 [in Ukrainian].

7. (2017). Zakon Ukrayiny vid 06.04.2017 № 2002 VIII «Pro vnesennya zmin do deyaky zakonodavcho aktiv Ukrayiny otnosytelno udoskonalennya zakonodavstva po voprosam diyalnosti zakladiv okhorony zdoroya». [Law of Ukraine dated 06.04.2017 No.2002-VIII "On amendments to certain legislative acts of Ukraine concerning the improvement of legislation on the activities of health care institutions"]. Retrieved from: https://zakon.rada.gov.ua/laws/show/2002-19\#Text [in Ukrainian]. 8. (2015). Zakon Ukrayiny vid 24.11.2015 № 817-VIII «Pro vnesennya zmin do deyaky zakoniv Ukrayiny vidnosno usunennya rehulyatornykh baryeriv dlya rozvytku derzhavno-pryvatnoho partnerstva ta stymulyuvannya investytsiy $v$ Ukrayini» [Law of Ukraine of 24.11.2015 No. 817-VIII "On amendments to certain laws of Ukraine on elimination of regulatory barriers to the development of public-private partnerships and stimulation of investments in Ukraine"]. Retrieved from: https://zakon.rada. gov.ua/laws/show/817-19.\#Text [in Ukrainian].

9. (2012). Zakon Ukrayiny pro derzhavno-chastnoe partnerstvo Vidomosti Verkhovnoyi Rady Ukrayiny (VVR), 2010, № 40, st.524. Iz zminami, vnesenymy sohlasno iz Zakonamy VVR N 5007-VI (5007-17) vid 21.06.2012, 16.10.2012 [Law of Ukraine On Public-Private Partnership News Verkhovna Rada of Ukraine (NVR), 2010, No. 40, p.524.]. Retrieved from: https://zakon.rada.gov.ua/laws/show/2404-17\#Text [in Ukrainian].

10. Kredisov, A.I. \& Bilous, A.A. (2016). Derzhavno - pryvatne partnerstvo: svitovyy dosvid i yoho vykorystannya v Ukrayini [Public-private partnership: world experience and its use in Ukraine]. Ekonomika Ukrayiny - Economy of Ukraine, 2 (643), 5-15 [in Ukrainian].

11. Krutiy, O.M. \& Radchenko, O.V. (2018). Osnovy partnerskoyi vzayemodiyi derzhavy y pryvatnoho sektora [Fundamentals of partnership relations between the state and the private sector]. Teoriya ta praktyka derzhavnoho upravlinnya - Theory and Practice of Sovereign Government, 3 (50), 73-83 [in Ukrainian]. 


\section{CONCEPTUAL FUNCTIONAL AND ORGANIZATIONAL MODEL OF THE REGIONAL CENTER OF CARDIOLOGY ON THE PRINCIPLES OF PPP}

A. V. Ivanyuk

Kyiv Regional Clinical Hospital, Kyiv, Ukraine

Purpose: to substantiate the conceptual functional - organizational model of the regional center of cardiology (RCC) on the principles of public-private partnership (PPP)

Materials and Methods. The study used general scientific methods of analysis, synthesis, generalization, modeling, interpretation of scientific data, as well as systemic and structural-functional approaches.

Results. To solve the problem of financing and development of the most expensive tertiary highly specialized cardiac care for the population of the region, a project was implemented to substantiate the conceptual functional and organizational model of the RCC on the principles of PPP, ie combining forces and means of state and business.

A model of the RCC has been developed on the principles of PPP as an economically and legally independent subject of medical activity, providing an optimal mix of state regulation and market self-regulation.

The economic efficiency of the developed RCC model is achieved due to the legal and economic independence of the model, multichannel financing and profitability of commercial activities.

Medical care in the RCC model is presented in two directions - medical and medical-social (free of charge) and economically profitable - paid, each of which is focused on its own consumer of services.

The organizational structure of the model - RCC on the principles of PPP integrates three centers: a center for highly specialized inpatient care, a center for outpatient and outpatient emergency and planned consultations, a center for organizational methodological, information-analytical, integration and statistical work, as well as two blocks - administrative and economic and support units.

The patient-oriented model ensures the availability of highly specialized medical care for various categories of the population.

Conclusions. The potential of the RCC model based on PPP principles is focused on self-sufficiency, business processes and the integration of medical services, ensures its economic, medical and social efficiency and an optimal functioning in market conditions. The implementation of the RCC model into practice will allow to fulfill the target function of the model - to meet the population needs of the region for affordable and high-quality technologically advanced cardiac services

KEY WORDS: regional center of cardiology; public-private partnership; tertiary level of cardiac care; financing of medical care.

Рукопис надійшов до редакції 10.08.2021 р.

\section{Відомості про автора:}

Іванюк Анатолій Вікторович - кандидат медичних наук, завідувач Центру кардіохірургії Київської обласної клінічної лікарні; тел.: +38(044) 237-02-86. 